\title{
EFFECT OF UNCOMBINED CALCIUM AND MAGNESIUM ON THE MALLEABILITY OF NICKEL ALLOYS
}

John J. deBarbadillo

The International Nickel Company, Inc.

Paul D. Merica Research Laboratory, Suffern, NY

\author{
ABSTRACT
}

Calcium and magnesium are added to many $\mathrm{Ni}-\mathrm{Cr}-\mathrm{Fe}$ alloys to improve their malleability. It is generally regarded that these elements operate by neutralizing embrittling impurities such as sulfur and oxygen. However, it is also known that an excess of uncombined calcium or magnesiun can cause severe hot shortness. This paper identifies the specific mechanism causing the loss of ductility in calcium and magnesium treated alloys and defines processing factors which influence sensitivity to embrittlement.

The paper defines the solid solubility of magnesium and calcium in $\mathrm{Ni}-\mathrm{Cr}-\mathrm{Fe}$ alloys and catalogs the $\mathrm{Ni}-\mathrm{Ca}$ and $\mathrm{Ni}-\mathrm{Mg}$ intermetallic compounds. Extensive use of electron microprobe analysis was made in the phase identification. The effect of cooling rate during solidification and soaking time on the volume fraction and distribution of magnesium- and calcium-rich phases is also discussed.

The second section of this paper deals with the hot workability of alloys containing uncombined calcium and magnesium. The results obtained with a simple upset forging test are interpreted in terms of the volume fraction, morphology and melting point of the magnesium- and calcium-xich phases. 


\section{Introduction}

For many years calcium and magnesium have been added to $\mathrm{Ni}-\mathrm{Cr}-\mathrm{Fe}$ alloys to improve their malleability. It is generally regarded that these elements operate by neutralizing embrittling impurities such as sulfur and oxygen. Improved castability, oxidation resistance and mechanical properties have also been reported and in some alloys a specific residual level of these elements is required. However, in some alloys an excess of calcium or magnesium results in severe hot shortness and, due to erratic recovery, caution is necessary in treating alloys known to be particularly sensitive to "overtreatment". Although the subject is of great importance for alloy producers, it has been dealt with for the most part on a phenomenologica] basis. This approach has led to practical treatment guidelines but modern alloys are so complex that unnoticed factors and synergisms make a purely empirical approach hazardous. To fill this apparent gap in our understanding of this subject the present program sought to identify the specific mechanism causing the loss of ductility in calcium and magnesium treated alloys and to define processing factors which influence sensitivity to embrittlement.

Calcium- and Magnesium-Rich Phases in Nicke1-Base Alloys

The Ni-Ca and Ni-Mg binary diagrams (Figs. 1,2) provide a basis for understanding the behavior of these elements in more complex alloys. Examination of these systems shows similarities; i.e., unlimited liquid solubility, restricted solubllity in solid $\mathrm{Ni}$ and presence of Ni-rlch lowmelting intermetallic compounds. These compounds are extremely brittle and at temperatures near their melting points they are subject to catastrophic oxidation. Some phases, such as $\mathrm{NiMg}_{2}$ and $\mathrm{Ni} 2 \mathrm{Ca}$, are also severely attacked when exposed to water.

Nickel is one of the few transition metals which alloys with $\mathrm{Ca}$ and $\mathrm{Mg}$. These elements are practically insoluble in pure liquid $\mathrm{Cr}$, Mo, $\mathrm{Nb}$ and $\mathrm{Ti}$, have limited solubility in liquid $\mathrm{Fe}$ and $\mathrm{Co}$, and form no intermetallic compounds with any of them(5). The ternary $\mathrm{Ni}-\mathrm{Ca} / \mathrm{Mg}-$ transition metal systems are similar in many respects. For the sake of brevity the $\mathrm{Ni}-$ $\mathrm{Ca} / \mathrm{Mg}-\mathrm{Fe}$ systems will be used as examples in the following discussions. Data on the important $\mathrm{Ni}-\mathrm{Ca} / \mathrm{Mg}-\mathrm{Cr}$ and $\mathrm{Ni}-\mathrm{Ca} / \mathrm{Mg}-\mathrm{Mo}$ systems will be presented as needed for clarification.

The estimated liquidus surfaces for the $\mathrm{Ni}-\mathrm{Ca} / \mathrm{Mg}-\mathrm{Fe}$ systems are shown in (Figs. 3,4). Also, ranges of occurrence of the $\mathrm{Ca}$ - and $\mathrm{Mg}-\mathrm{rich}$ phases in solid $\mathrm{Fe}-\mathrm{Ni}$ alloys are indicated. The phase distribulion ranges in the analogous $\mathrm{Ni}-\mathrm{Ca} / \mathrm{Mg}-\mathrm{Cr}$ and $\mathrm{Ni}-\mathrm{Ca} / \mathrm{Mg}-\mathrm{Mo}$ alloys are listed in Table $\mathrm{T}$. The diagrams were constructed from data collected on a large number of $10 \mathrm{~kg}$ laboratory heats. The phase compositions were determined by electron microprobe.

A number of points are evident from the ternary diagrams. No $\mathrm{Mg}-$ or Carich phase other than those present in binary Ni-Ca and Ni-Mg systems are formed in either system. Further, all of the binary $\mathrm{Ni}-\mathrm{Ca}$ and $\mathrm{Ni}-\mathrm{Mg}$ phases have been observed in $\mathrm{Ni}-\mathrm{Fe}$ alloys. To a limited extent Fe can replace $\mathrm{Ni}$ in all of these phases. The very low melting point of constituents formed during solidification of Fe-Ni alloys is of great significance. The same phases occur in the $\mathrm{Ni}-\mathrm{Cr}$ and $\mathrm{Ni}-\mathrm{Mo}$ systems but the ranges of occurrence are shifted (Table I). 


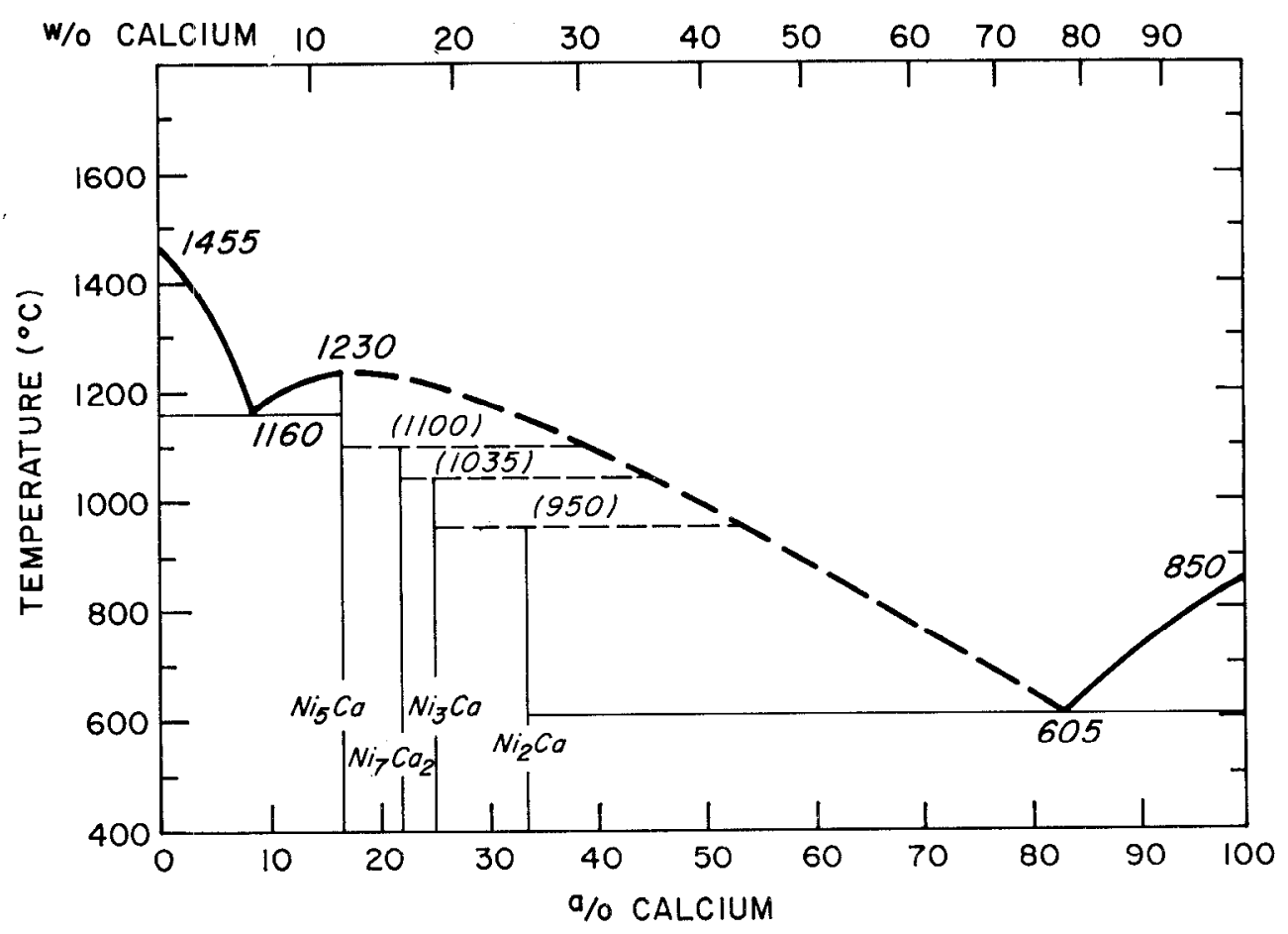

FIGURE I - NICKEL - CALCIUM BINARY DIAGRAM. (REFS. 1-3)

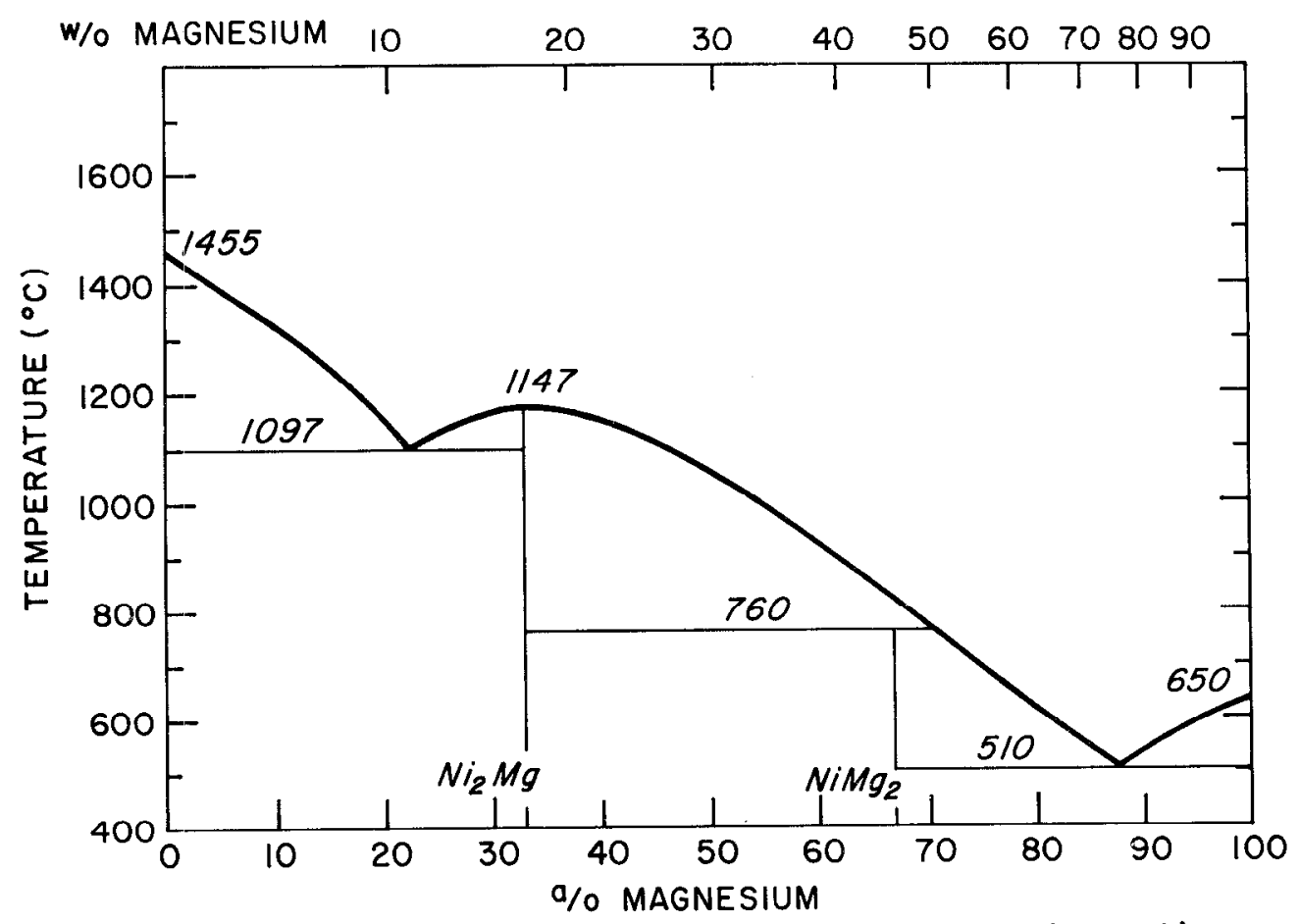

FIGURE 2 - NICKEL-MAGNESIUM BINARY DIAGRAM. (REF. 4) 
FIGURE 3

ESTIMATED LIQUIDUS SURFACF.

IN Fe-Ni-Ca SYSTEM AND

RANGE OF CALCIUM-RICH

PHASES OBSERVED AFTER

SOLIDIFICATION OF $\mathrm{Fe}-\mathrm{Ni}$

ALLOYS

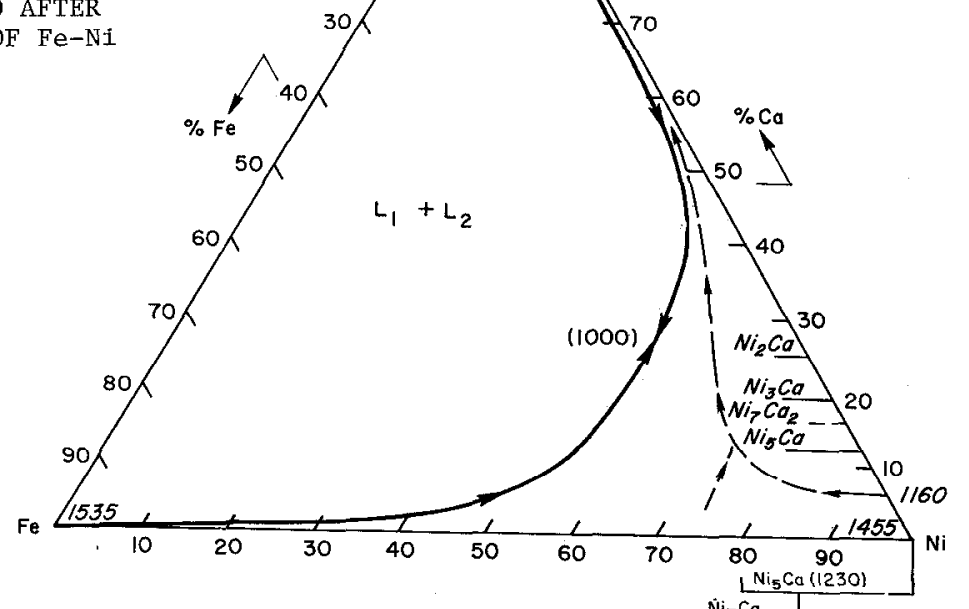

$\mathrm{Ni}_{3} \mathrm{Ca}(1035)$

$\mathrm{Ni}_{7} \mathrm{Ca}_{2}$

$\mathrm{Ni}_{2} \mathrm{Co}(95 \mathrm{O})$

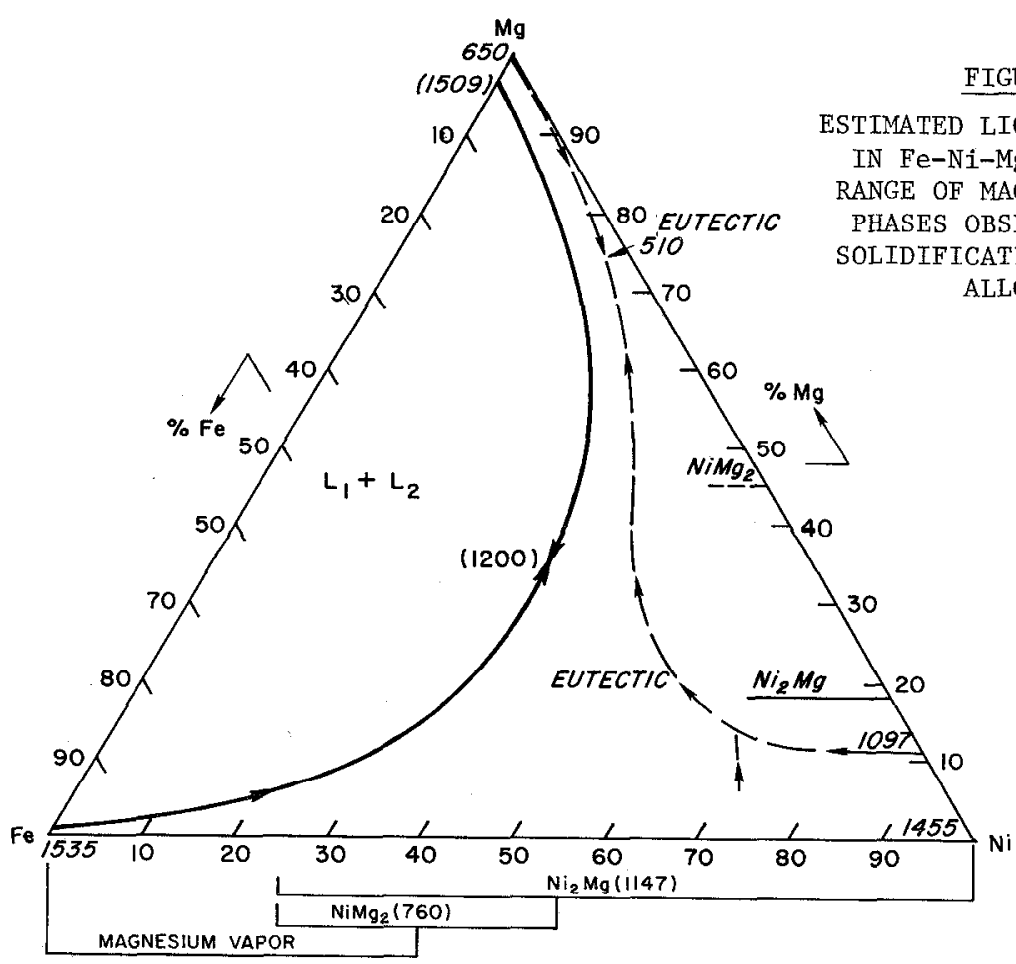

FIGURE 4

TIMATED LIQUIDUS SURFACE

Fe-Ni-Mg SYSTEM AND

MAGNESIUM-RICH

PIIASES OBSERVED AFTER

ATION OF $\mathrm{Fe}-\mathrm{Ni}$

ALOYS 


\section{Table I}

Approximate Range of Occurrence and Composition of Calcium and Magnesium Phases in Ni-Fe, Ni-Cr and Ni-Mo Alloys*

\begin{tabular}{|c|c|c|c|c|c|c|c|c|}
\hline \multirow[b]{2}{*}{ Base } & \multicolumn{5}{|c|}{ Calcium Phases } & \multicolumn{3}{|c|}{ Magnesium Phases } \\
\hline & $\mathrm{Ni}_{5} \mathrm{Ca}$ & $\mathrm{Ni}_{7} \mathrm{Ca}_{2}$ & $\mathrm{Ni}_{3} \mathrm{Ca}$ & $\mathrm{Ni}_{2} \mathrm{Ca}$ & $\mathrm{Ca}$ & $\mathrm{i}_{2} \mathrm{Mg}$ & $\mathrm{NiMg}_{2}$ & $\mathrm{Mg} * *$ \\
\hline \multirow[t]{2}{*}{$\mathrm{Ni}-\mathrm{Fe}$} & 1 & 88 & $88-60$ & & & 100 & & \\
\hline & & & 6.0 & & & 1 & & \\
\hline \multirow[t]{2}{*}{$\mathrm{Ni}-\mathrm{Cr}$} & $100-85$ & $92-80$ & $92-70$ & 92 & 92 & $100-35$ & 35) & $(45)-0$ \\
\hline & & 2. & 2. & & $\mathrm{~N}$ & 6.9 & & Ni1 \\
\hline \multirow[t]{2}{*}{$\mathrm{Ni}-\mathrm{Mo}$} & $100-90$ & $95-85$ & $95-75$ & $95-60$ & $95-0$ & $100-50$ & $(65-35)$ & $(50)-0$ \\
\hline & $\mathrm{Nil}$ & $\mathrm{Nil}$ & $\mathrm{Ni1}$ & $\mathrm{Nil}$ & $\mathrm{Nil}$ & Nil & (Nil) & Ni1 \\
\hline
\end{tabular}

* First entry - range of occurrence expressed as nickel content of base alloy; second entry - maximum amount of $\mathrm{Fe}, \mathrm{Cr}$ or $\mathrm{Mo}$ in phase (w/o).

**Pure magnesium will almost always vaporize during solidification.

The prediction of $\mathrm{Ca}$ and $\mathrm{Mg}$ phases in multicomponent commercial alloys is fairly straightforward. The phase distribution range for a complex alloy can be estimated by converting the actual composition to an Fe equivalent (F.E.) using the formulas:

$$
\begin{aligned}
& \text { F.E. (Ca) }=\% \mathrm{Fe}+1.3 \% \mathrm{Cr}+1.5 \% \mathrm{Mo}+0.5 \% \mathrm{Co} \\
& \text { F.E. }(\mathrm{Mg})=\% \mathrm{Fe}+1.1 \% \mathrm{Cr}+1.2 \% \mathrm{Mo}
\end{aligned}
$$

Elemenls such as $W$, Ta, $N b$ and $T i$ probably have effects similar to that of Mo. $\mathrm{Cu}$, Co in $\mathrm{Mg}$ treated alloys and probably $\mathrm{Al}$ are similar to $\mathrm{Ni}$ in their effect on phase balance. It must be emphasized that these equations provide only rough predictions of the phases to be expected in a given alloy.

While the equilibrium solubility of $\mathrm{Ca}$ and $\mathrm{Mg}$ in solid $\mathrm{Ni}$ is on the order of 0.1 to $0.5 \mathrm{w} / \mathrm{o}$, segregation during freezing is severe. In practice $\mathrm{Mg}-$ and $\mathrm{Ca}-\mathrm{rich}$ phases are visible at solute concentrations of $0.05 \%$ and microprobe analyses of as-cast alloys indicate that the amount in solution is $0.01 \%$ or less. Solubility in the solid is decreased by ternary solutes such as $\mathrm{Fe}, \mathrm{Cr}$ and $\mathrm{Mo}$. The Iimited data for the $\mathrm{Ni}-\mathrm{Fe}$ system obtained in the present study are shown, (Fig. 5).

Since the $\mathrm{Ca}$ and $\mathrm{Mg}$ contents of the binary phases are dependent on the matrix composition, it also follows that the volume fraction of the phases will vary. The volume of second phases in Fe-Ni alloys containing $0.01 \%$ uncombined $\mathrm{Ca}$ or $\mathrm{Mg}$ was calculated and plotted in Fig. 5. Note that in each system the volume fraction increases with increasing $\mathrm{Ni}$ content. The volume fraction of $\mathrm{Mg}-$ rich phase is zero in alloys containing less than $25 \%$ $\mathrm{Ni}$ because all uncombined $\mathrm{Mg}$ was assumed to vaporize when the ingot solidifies. The calculated volumes may appear trivial, but if present as an intergranular film in an alloy with a grain diameter of $1 \mathrm{~mm}$ complete coverage of the grain boundaries with a layer $0.4 \mu \mathrm{m}$ thick would result.

Microstructures of ra-rich phases in selected Ni-hase a11oys are shown in Fig. 6. Phase identification was made by microprobe analysis. Calcium levels in the examples shown are higher than those of commercial alloys but examination of a large number of alloys established that the morphology was identical to the limit of second phase detectability. Note the strong tendency of $\mathrm{Ni}{ }_{5} \mathrm{Ca}, \mathrm{Ni}_{7} \mathrm{Ca}_{2}$ and $\mathrm{Ni}_{3} \mathrm{Ca}$ to wet grain boundaries and form essentially continuous films. On the other hand $\mathrm{Ni}_{2} \mathrm{Ca}$ and especially pure $\mathrm{Ca}$ were glowilar even where they were present at grain boundaries. Sample preparation procedure proved to be quite important in revealing the structure of the calcium-rich phases. After grinding on dry papers, diamond polish- 


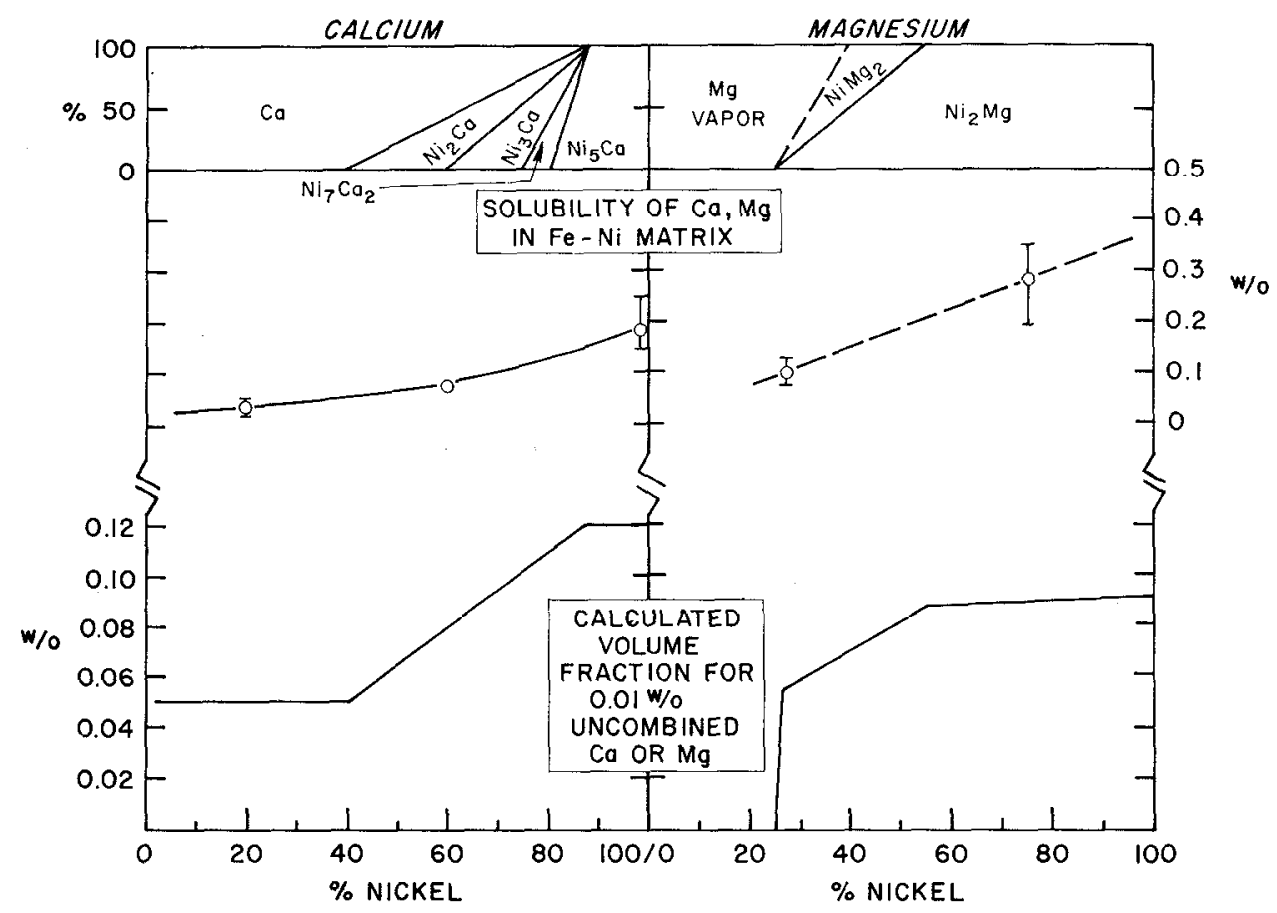

FIGURE 5 - DISTRIBUTION AND VOLUME FRACTION OF PHASES; SOLID SOLUBILITY FUR Fe-Ni ALLOYS.

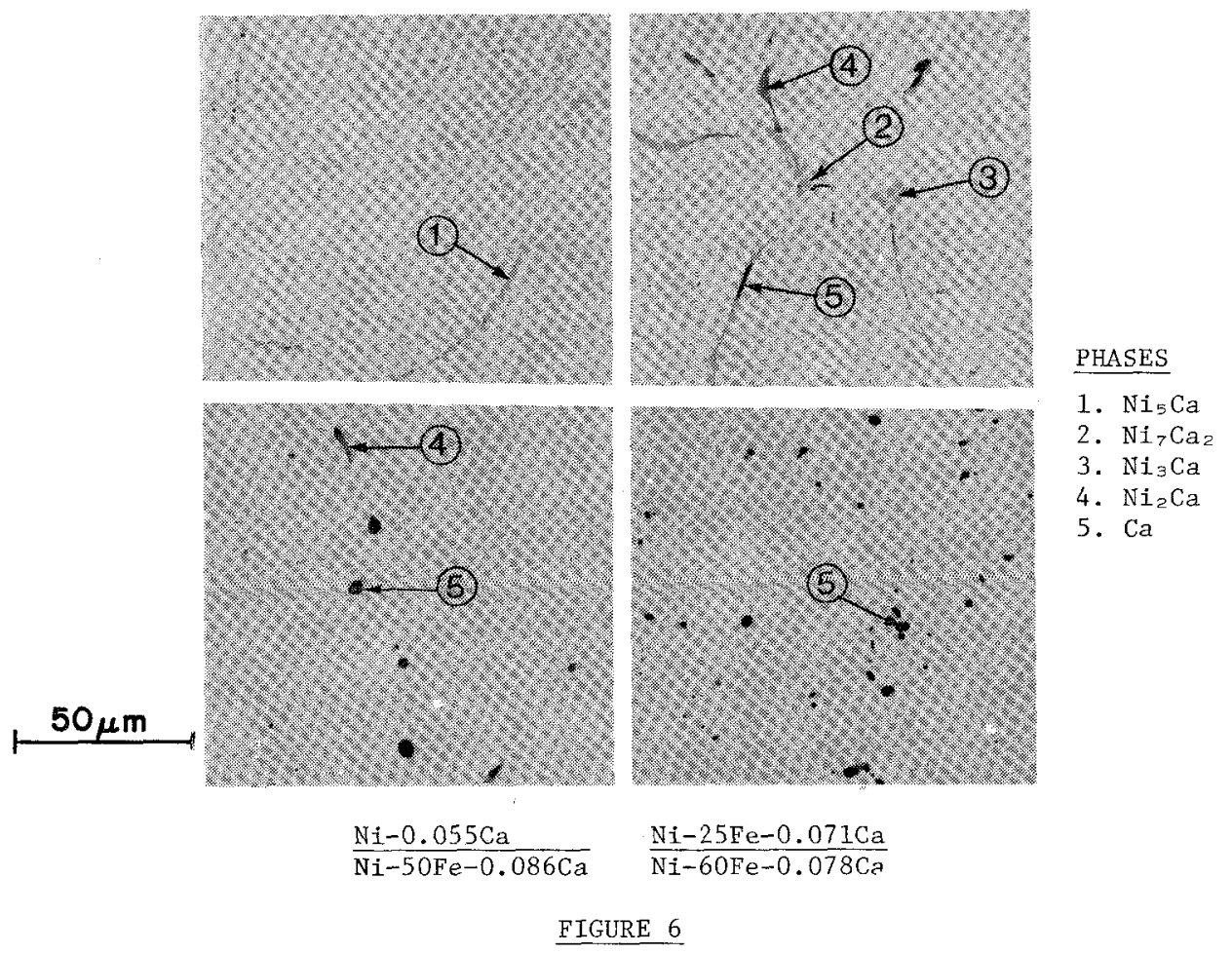

CALCIUM-RICH PHASES FORMED DURING SOLIDIFICATION OF SELECTED Ni-Fe-Ca ALLOYS 
ng in kerosene was employed. A final touch on $0.01 \mu \mathrm{m}$ alumina on a moistened lap was sufficient to bring out the microstructure. The polishing and etching procedures normally used for $\mathrm{Ni}$ alloys resulted in dissolution of the second phase. Hence it is understandable that these phases had previously escaped the notice of most metallurgists.

Microstructures of Mg-rich phases in Ni-base alloys are shown in Fig. 7. Grain boundary films of both the $\mathrm{Ni}_{2} \mathrm{Mg}$ and $\mathrm{NiMg} 2$ phases were observed only at relatively high $\mathrm{Mg}$ contents. Generally, when the Mg content was less than about $0.1 \%$ the particles were globular or irregular. The presence of $\mathrm{Cr}$ and Mo also seems to favor a more irregular, discontinuous phase structure (Fig. 7b). The phase $\mathrm{Ni}_{2}\left(\mathrm{MgXC}_{1-\mathrm{x}}\right)$ was also occasionally observed (Fig. $7 d$ ). This phase is unlikely to occur in commercial Ni-base alloys because it is suppressed by carbide stabilizing elements such as $\mathrm{Cr}$ and $\mathrm{Mo}$.
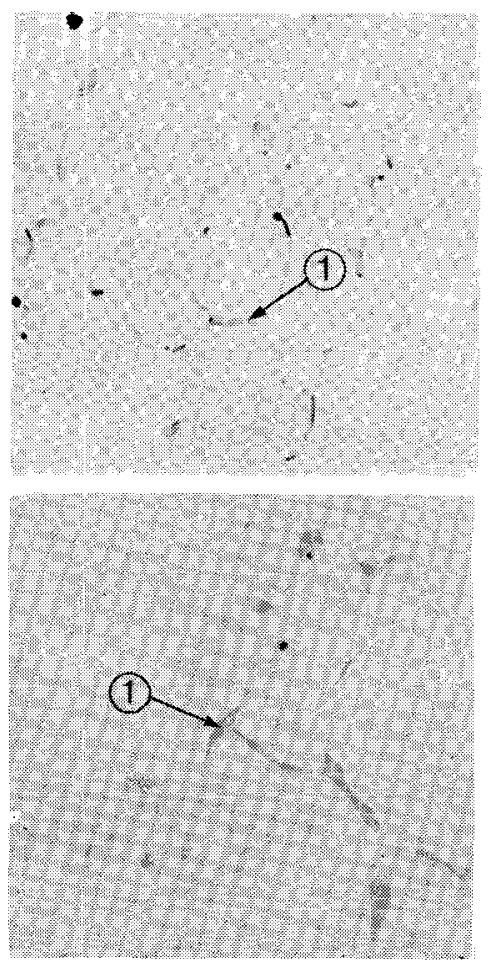

$\mathrm{Ni}-14 \mathrm{Cr}-0.19 \mathrm{Mg}$

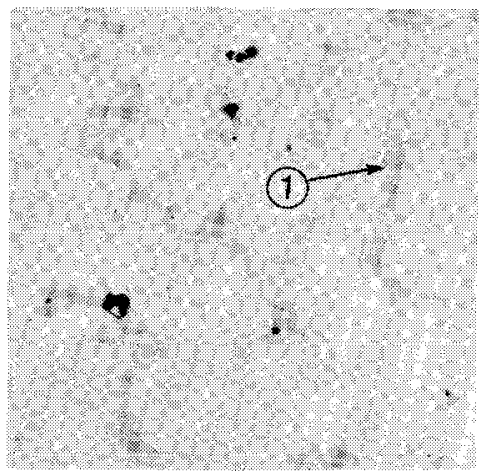

PHASES

1. $\mathrm{Ni}_{2} \mathrm{Mg}$

2. $\mathrm{Ni}$. $\left(\mathrm{Mgx}_{\mathrm{X}} \mathrm{C}_{1-\mathrm{x}}\right)$

3. $\mathrm{NiMg}$

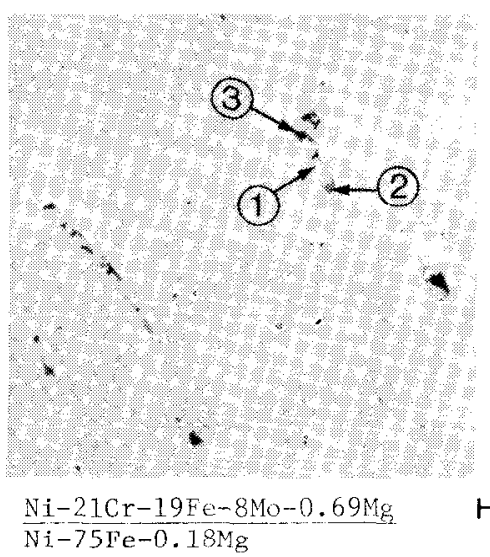
$50 \mu \mathrm{m}$

FIGURE 7 - MAGNESIUM-RTCH PHASES FORMED DURING SOLIDIFICATION OF SELECTED Ni-Fe-Cr-Mg ALLOYS

Malleability of Calcium and Magnesium Treated Alloys

As mentioned previously $\mathrm{Ni}-\mathrm{Ca}$ and $\mathrm{Ni}-\mathrm{Mg}$ phases are extremely brittle. Consequently, it is not surprising that alloys in which the second phase was readily visible in the microscope were cold short. However, it was felt that alloys containing such large volumes of $\mathrm{Ca}$ - or $\mathrm{Mg}-\mathrm{rich}$ phases would also be hot short. Consequently, work was concentrated on derinillg the effect of these elements on hot workability. The scope of the potential hot shortness problem is illustrated in Fig. 8 which shows the melting points of the phases superimposed on their range of occurrence in Fe-Ni alloys. Clearly these phases would be liquid at the normal hot working temperatures of most commercial alloys. 


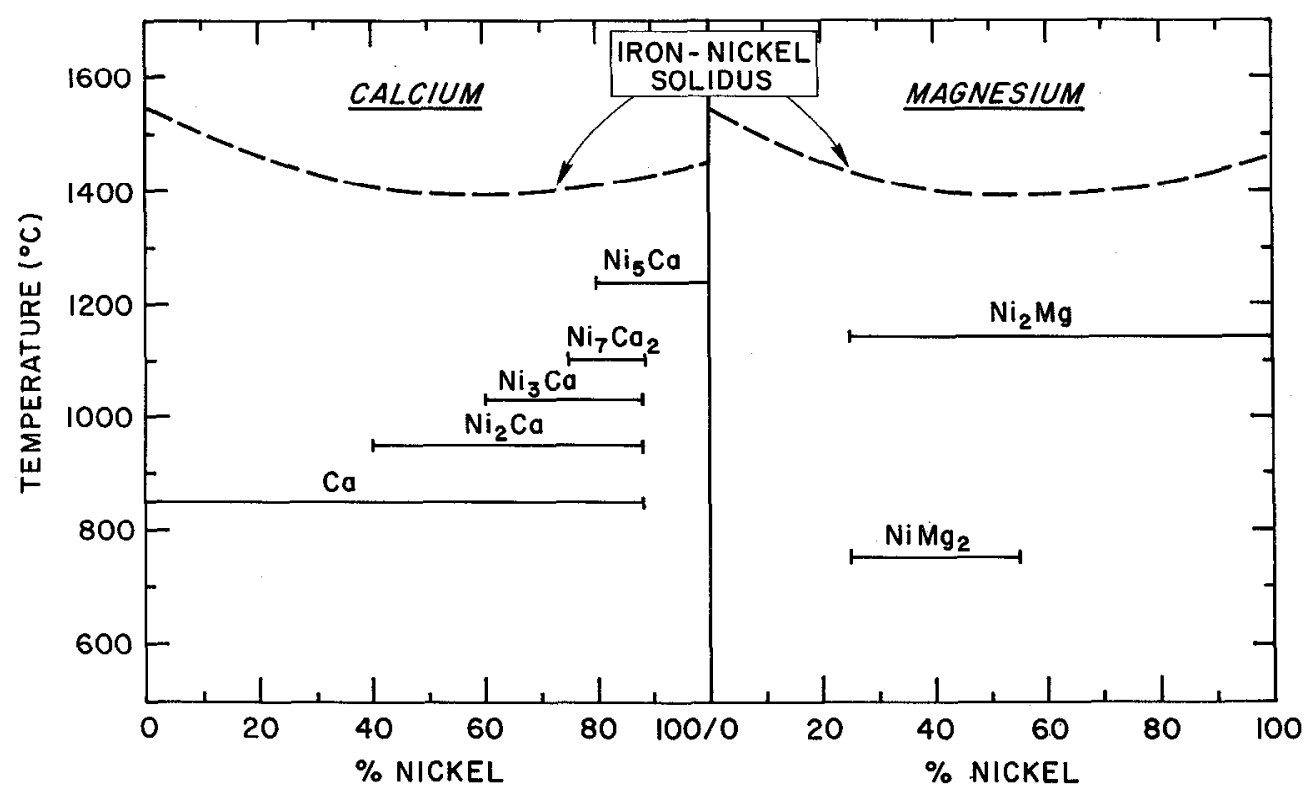

FIGURE 8 - MELTING POINT OF CALCIUM AND MAGNESIUM-RICH PHASES AND THEIR REGION OF FORMATION IN IRON-NICKEL ALLOYS.

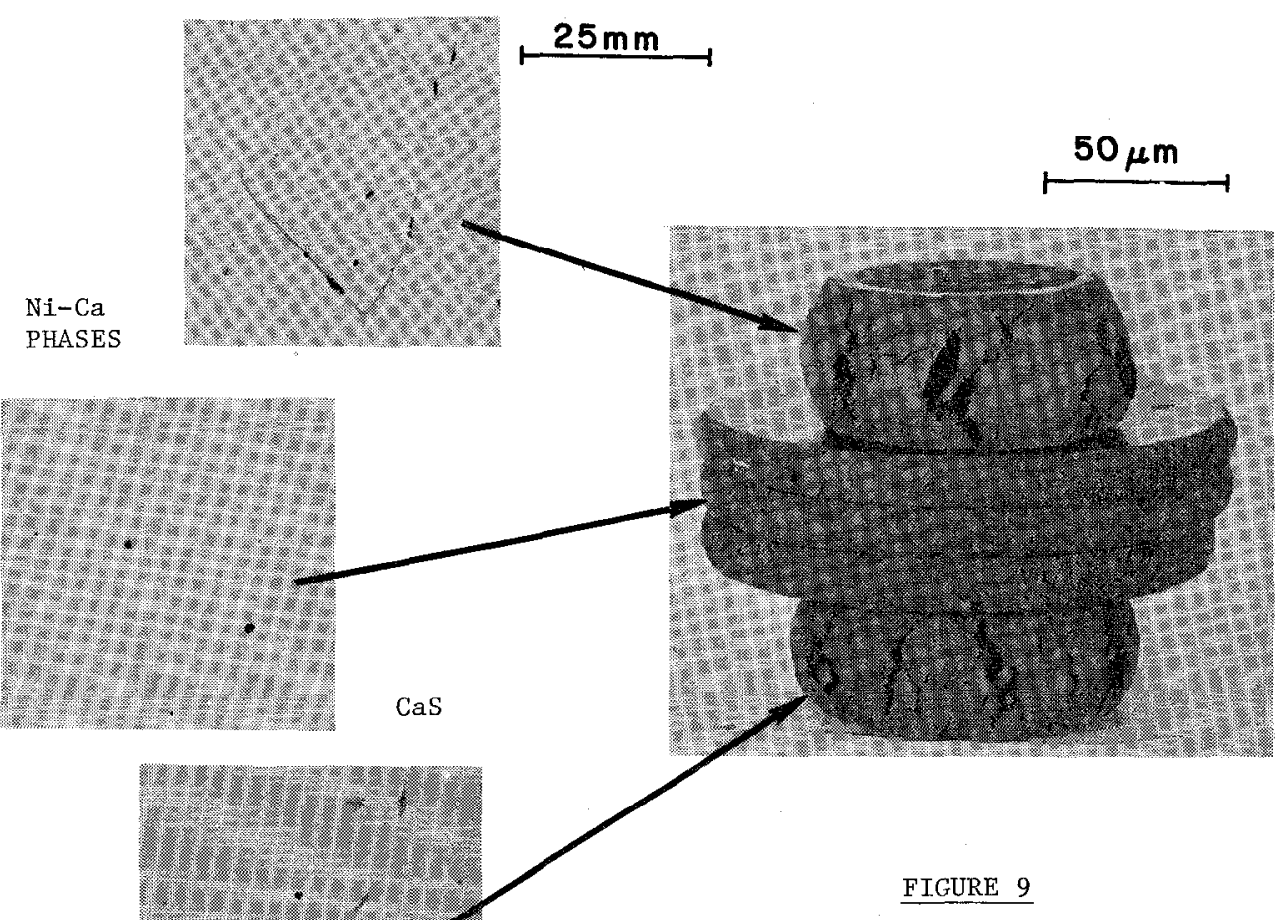

EFFECT OF CALCTUM ON HOT

WORKABILITY AND MICRO-

STRUCTURE OF $\mathrm{Ni}$-30Fe ALLOY 
The test of hot workability used in this study, although relatively crude, proved quile useful for screening a wide range of alloy compositions. The test specimen was a cast cylinder $65 \mathrm{~mm}$ high and $30 \mathrm{~mm}$ in diameter. The cylinders were soaked in air in a muffle furnace for one hour and then upset forged to the point where cracking occurred. Most of the alloys were prepared as series of split heats in which $\mathrm{Ca}$ or $\mathrm{Mg}$ additions were varied for a given matrix composition. Typical addition levels were $0.02,0.04$, $0.06,0.12$ and $0.25 \%$. Forged cylinders for a Ni-30Fe alloy are shown in Fig. 9. This series contained $0.02 \% \mathrm{~S}$ to illustrate the role of $\mathrm{Ca}$ in alleviating the embrittling effect of $\mathrm{S}$. A similar series with $\mathrm{Mg}$ additions gave comparable results. Sulfur was not added to most of the alloys since the program objective was to study the effect of uncombined $\mathrm{Ca}$ and $\mathrm{Mg}$.

The effect of $\mathrm{Ca}$ on the hot workability of selected Ni-Fe alloys is illustrated in Fig. 10. This series shows that hot cracking is most severe at about $75 \mathrm{Ni}-25 \mathrm{Fe}$ and that sensitivity to uncombined $\mathrm{Ca}$ is greatly diminished in high-Fe alloys. In the Ni-Cr and Ni-Mo systems the greatest sensitivity to cracking occurred at about $15 \% \mathrm{Cr}$ and $10 \% \mathrm{Mo}$, respectively. Otherwise, they were analogous to the Ni-Fe system. The observed behavior can be explained by the microstructural informatior presented earlier.

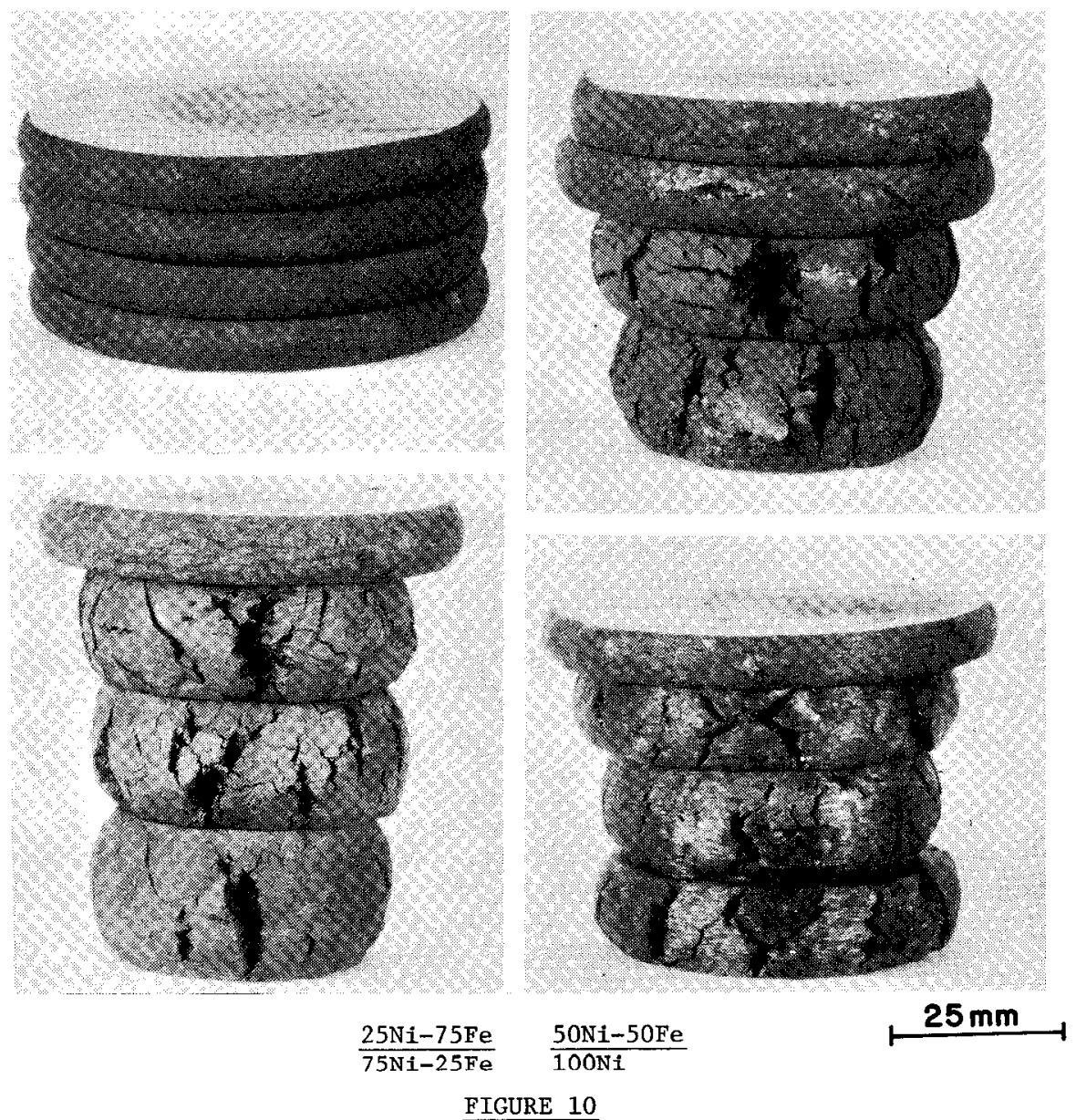

EFFECT OF CALCIUM ON HOT WORKABILITY OF NICKEL-IRON ALLOYS. AS-CAST CYLINDERS FORGED AT $982^{\circ} \mathrm{C}$. 

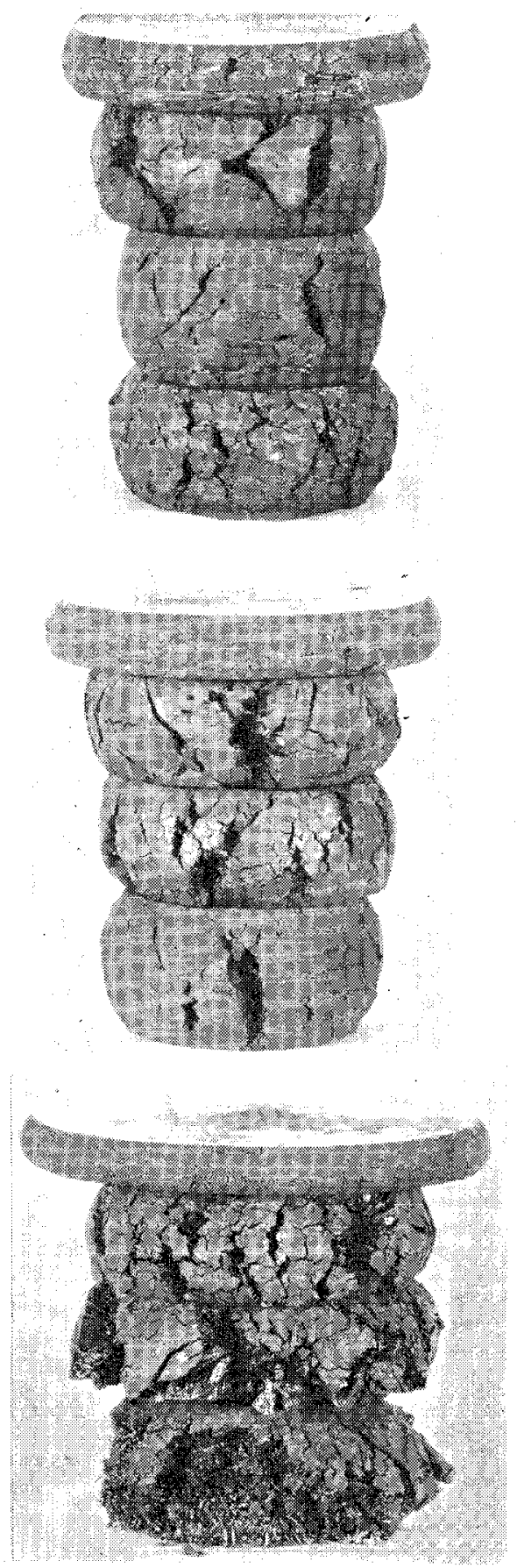

a-c) Cálcium Treated
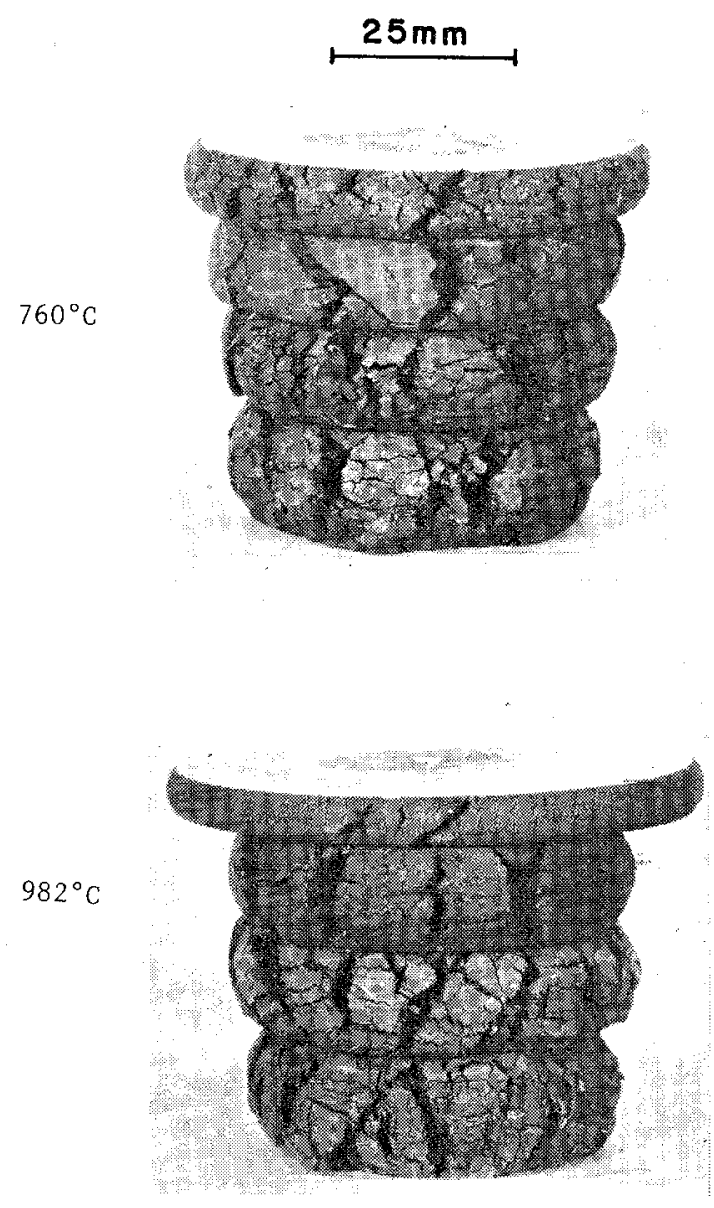

$1204^{\circ} \mathrm{C}$

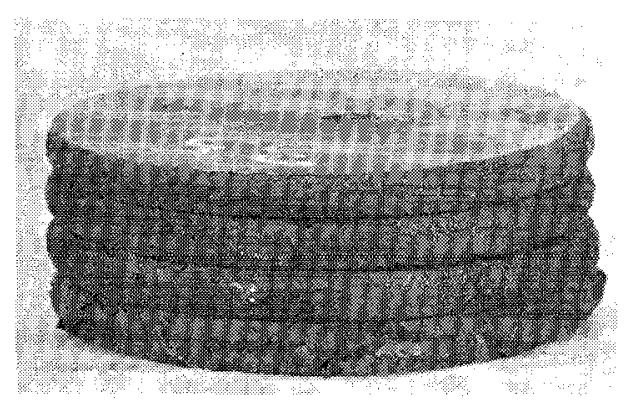

d-f) Magnesium Treated

FIGURE 11

EFFECT OF FORGING TEMPERATURE ON THE HOT WORKABILITY OF CALCIUM TREATED

$\mathrm{Ni}-25 \mathrm{Fe}$ ALLOYS. AS-CAST SLUCS FORGED AT INDICATED TEMPERATURT. 
The most severe cracking occurred in the alloys which have the worst combination of three factors: high volume fraction and low melting point of a continuous grain boundary film. Sensitivity is lower in high-Ni alloys when the higher melting point $\mathrm{Ni}_{5} \mathrm{Ca}$ phase is present, and in high-Fe alloys because the volume fraction and continuity of the second phase are diminished.

The effect of forging temperature on hot workability of the N:-25Fe alloy is shown in Fig. 1la-c. This series was represcntative of the behavior of all Ca-treated alloys. Note the cold cracking in all samples forged at $760^{\circ} \mathrm{C}$ and the gross hot shortness of samples forged at $1204^{\circ} \mathrm{C}$.

It was evident from the microstructures of forged alloys in the previous series that little agglomeration or resolution occurred during the one hour soak prior to forging. However, the solid solubility data for $\mathrm{Ca}$ in $\mathrm{Ni}$ alloys (Fig. 5) suggcsted that prolonged soaking might dissolve or spheroidize the Ca-rich phases and thereby improve malleability. To check this, specimens were soaked for 1000 minutes ( $17 \mathrm{hrs.}$ ) at $1204^{\circ} \mathrm{C}$ and then forged. As shown in Fig. 12, there was virtually no tendency for spheroidization of the $\mathrm{Ni}{ }_{5} \mathrm{Ca}$ phase. Microprobe measurements showed that there was an increase in the $\mathrm{Ca}$ content of the matrix (maximum $0.08 \mathrm{w} / \mathrm{o}$ near the particles) but clearly dissolution is an extremely slow process at these temperatures. The prolongcd soaking actually degraded the forgeability slightly. This was attributed to preferential oxidation of the Ca-rich phase. Note the internal oxidation visible in the micrograph.
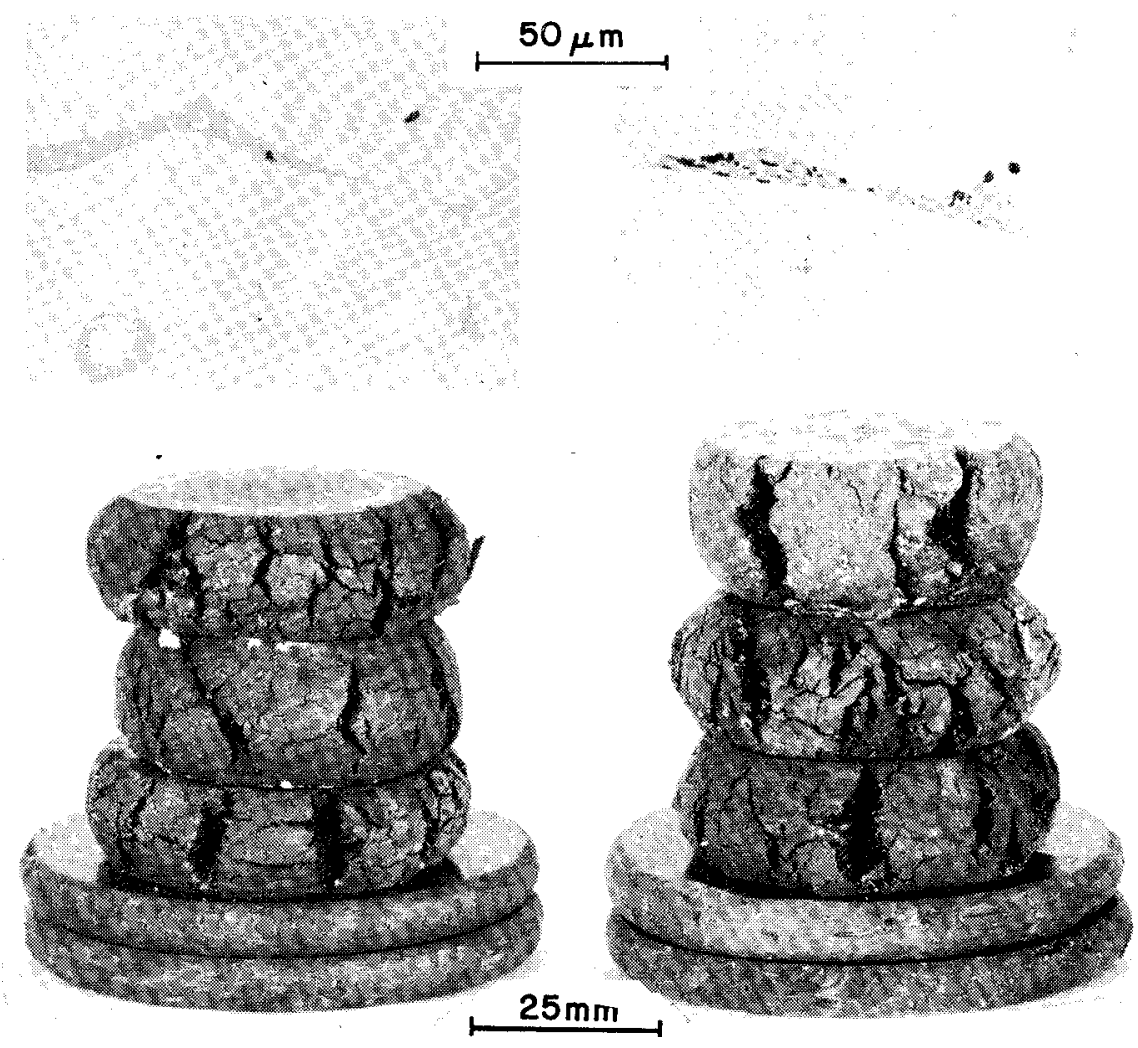

a) Soaked $60 \mathrm{Min}$ at $1204^{\circ} \mathrm{C}$

b) Soaked $1000 \mathrm{Min}$ at $1204^{\circ} \mathrm{C}$

FIGURE 12 - EFFECT OF SOAKING ON HOT WORKABILITY AND MICROSTRUCTURE OF CALCIUM TREATED Ni-9.5Cr ALLOY 
In another experiment various size castings were prepared to see if cooling rate during solidification had any influence on the formation of $\mathrm{Ni}-\mathrm{Ca}$ phases. The castings ranged from $4 \mathrm{~mm}$ diameter chill samples to 90 $\mathrm{mm}$ slabs cooled in refractory brick molds. As expected the second phase particle size was considerably refined by rapid cooling but there was no effect on volume fraction or phase continuity.

The hot workability behavior of $\mathrm{Mg}$-treated $\mathrm{Ni}-\mathrm{Fe}$ alloys was quite different from that of Ca-treated alloys as shown in Fig. 13. In this system cracking severity increased with decreasing $\mathrm{Ni}$ content. Note however, that all alloys forged at $1204^{\circ} \mathrm{C}$ were far less sensitive to the presence of uncombined $\mathrm{Mg}$. Cracking became much more severe at lower forging temperatures (Fig. 11d-f). Again the observed behavior is consistent with the prior microstructural observations. Since the $\mathrm{Ni}-\mathrm{Mg}$ phases are less apt to be present as continuous grain boundary films, one would expect them to be less detrimental to malleability of $\mathrm{Ni}$ alloys than $\mathrm{Ni}-\mathrm{Ca}$ phases. Of even greater significance is the rapid dissolution of the $\mathrm{Ni}_{2} \mathrm{Mg}$ phase at temperatures above $1000^{\circ} \mathrm{C}$. This phase was completely dissolved during a one hour soak at $1204^{\circ} \mathrm{C}$ in alloys containing more than about $50 \% \mathrm{Ni}$. The $\mathrm{Mg}$ solubility in Fe-rich alloys is much lower as shown in Fig. 5, hence sensitivity to hot cracking was observed. Cold cracking during forging at $760^{\circ} \mathrm{C}$ and $980^{\circ} \mathrm{C}$ could be traced directly to fracturing of the brittle $\mathrm{Ni}_{2} \mathrm{Mg}$ particles which remained undissolved at those temperatures.
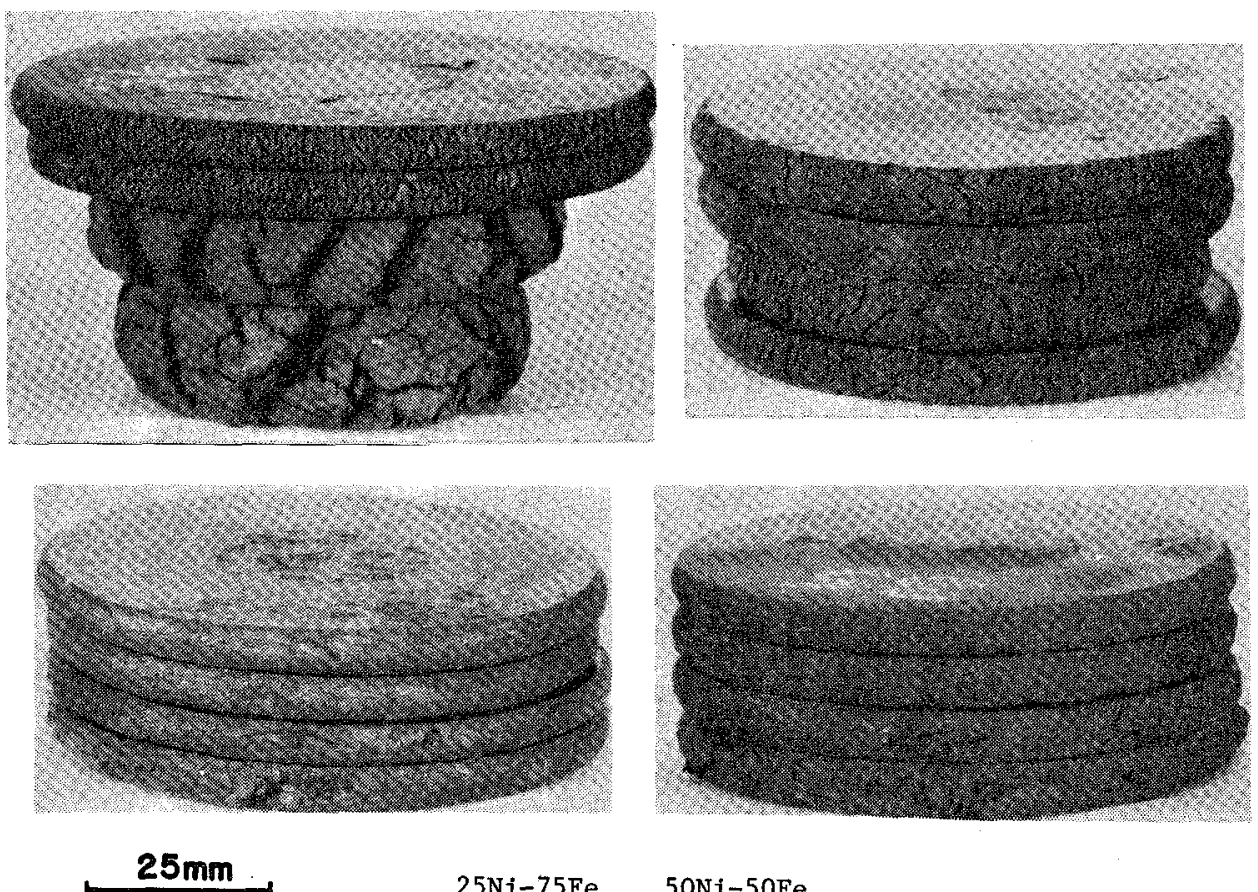

$$
\frac{25 \mathrm{Ni}-75 \mathrm{Fe}}{75 \mathrm{Ni}-25 \mathrm{Fe}} \quad \frac{50 \mathrm{Ni}-50 \mathrm{Fe}}{100 \mathrm{Ni}}
$$

FIGURE 13 - EFFECT OF MAGNESIUM ON HOT WORKABILITY OF NICKEL-IRON ALLOYS. AS-CAST CYLINDERS FORGED AT $1204^{\circ} \mathrm{C}$.

\section{Discussion}

The reason for poor ductility in Ni-base alloys which contain more than critical amounts of uncombined $\mathrm{Ca}$ or $\mathrm{Mg}$ has now been established. Hot shortness in forging results from the formation of continuous low melting point intergranular films of $\mathrm{Ni}-\mathrm{Ca}$ and $\mathrm{Ni}-\mathrm{Mg}$ phases during ingot solidification. As these compounds are extremely brittle, Ni alloys worked at 
low temperatures exhibit severe cold shortness. It had long been recognized that the malleability of $\mathrm{Ni}$ alloys was much more sensitive to $\mathrm{Ca}$ than $\mathrm{Mg}$. It now appears certain that this difference is due to the re1ative ease of dissolution of the $\mathrm{Ni}-\mathrm{Mg}$ phases and the persistence of $\mathrm{Ni}-\mathrm{Ca}$ films during soaking. While the mechanisms are now established, the question of translating these observations into practical guidelines remains.

In analyzing the behavior of any complex alloy system, the amount of uncombined $\mathrm{Ca}$ or $\mathrm{Mg}$ must first be established. In most alloys all of the residual oxygen and sulfur will be present as $\mathrm{CaO}, \mathrm{CaS}$, etc. Although $\mathrm{Ca}$ and $\mathrm{Mg}$ form nitrides, the presence of such compounds in $\mathrm{Ni}$ alloys has not been reported nor have interactions with other elements been observed. Consequently the uncombined $\mathrm{Ca}$ or $\mathrm{Mg}$ will be that remaining after the portion in the oxide and sulfide are accounted for. Sensitivity to cracking should then correlate with the level of uncombined $\mathrm{Mg}$ or $\mathrm{Ca}$.

The work reported here was performed largely on soft unstrengthened ternary alloys. Certainly the inherent strength and ductility of the matrix phase at the forging temperature will influence cracking sensitivity. Some tests were performed on Ni-base alloys containing AI, Co and various combinations of $\mathrm{Fe}, \mathrm{Cr}$ and Mo. The general forging behavior of these alloys was consistent with the preceding comments regarding the effect of these elements on second phase composition but in each case cracking was slightly more severe than in comparable binary alloys. Thus one must expect that alloys with large amounts of solid solution strengthening elements such as $\mathrm{Nb}$, $\mathrm{W}$, Ta, etc. will be more sensitive to the presence of uncombined $\mathrm{Ca}$.

Because of the relative ease of dissolution of $\mathrm{Ni}-\mathrm{Mg}$ phases during soaking, it seems unlikely that the amounts of $\mathrm{Mg}$ which are normally added to $\mathrm{Ni}$-base alloys would cause hot cracking. Permanent damage could result if overheating led to liquation and internal oxidation. Also hot working followed by warm working in a critical tempcrature range might 1ead to reprecipitation of $\mathrm{Ni}_{2} \mathrm{Mg}$ particles and reduced ductility. However, both problems are hypothetical and beyond the scope of the present paper.

It would appear from the foregoing discussion that the best way to avoid forging difficulties is to add only enough $\mathrm{Ca}$ or $\mathrm{Mg}$ to deoxidize or desulfurize. However, where a specific residual level is required for mechanical or physical properties this is not possible. For such materials a consistent recovery of the reactive element is essential if excessive ingot losses are to be avoic d. We have found that $\mathrm{Ca}$ and $\mathrm{Mg}$ recoveries of more than $90 \%$ can be achieved by using dilute Ni-base addition alloys such as $95 \mathrm{Ni}-5 \mathrm{Ca}$ or $95 \mathrm{Ni}-5 \mathrm{Mg}$. While these additives do not eliminate the need to maintain good treatment practices, they do ensure the melter consistent, predictable residual $\mathrm{Ca}$ and $\mathrm{Mg}$ leve1s.

\section{References}

1. H. Nowotny; Z. Metallkunde, Vo1. 34, 1942, pp. 247-253.

2. Y. Takeuchi, K. Muchizuki, M. Watanabe and I. Obinato; Metallwissenschaft und Technic, Vo1. 20, 1966, pp. 2-8.

3. K.H.J. Buschow; J. Less Common Metals, Vol. 38, 1974, pp. 95-98.

4. M. Hanson and K. Anderko; Constitution of Binary Alloys, Second Ed., McGraw-Hi11 Book Co., New York, 1958.

5. J.J. deBarbadillo; "Magnesium and Calcium Treatment of Nickel-Base Alloys"; Proceedings of 1975 American Vacinım Society Conference (microfische), available from Inco as T.P. 913. 